\title{
Understanding the Relationship Between Training, Motivation and Working Environment and Employee Performance in the Banking Sector in Bahrain
}

\author{
Fatema Ahmed $^{1 *}$, Qais Almaamari ${ }^{2}$ \\ * Student in Human resource Management, Gulf University, Kingdom of Bahrain \\ ${ }^{2}$ Assistant Professor, Gulf University, Kingdom of Bahrain
}

\author{
Article Info \\ Article history: \\ Received 27 December 2019 \\ Received in revised form 19 January 2020 \\ Accepted 27 February 2020 \\ Published 01 April 2020
}

\begin{abstract}
This paper aims to understand the impact of training, motivation, and work environment on the performance of the employee in the banking sector in Bahrain. This paper is a highlight of the literature review to identify the impact of training, motivation, and work environment on employee performance in the banking sector in Bahrain. This paper's findings helped the managers and human resources management who are responsible for employee performance at the organization, particularly in the banking sector in Bahrain. Further, that will give more practical implications and grasping to know the factors that impact the employee performance in the banking sector in Bahrain. So, the study and findings will be good resources to anyone involved in this field, and they grasp the matter deeply. The study paper will help the organization's human resource managers to understand the independent variables like training, motivation, and working environment that have an impact on employee performance in the banking sector in Bahrain.
\end{abstract}

Keywords: Training, Motivation, Work Environment, Employee Performance

\section{Introduction}

Workers' success is becoming more important and challenging for management in the changing environment and modern business period (Firth \& Carroll, 2016). Management is making a great deal of effort to fulfill the goals and objectives of the organization. Emphasizing perfection and gaining a strategic advantage, and helping to accomplish the goals is one of the efforts to achieve the targets. On the other hand, the staff is asked to be imaginative, versatile, inventive, and professionally qualified to perform the tasks effectively (ZEBERGA, 2019). It is evident that employees and staff are the greatest assets for any organization. The goals of the business depend on the success of the employee (Osabiya, 2015). The top management should also be mindful of the significance of costs when delivering training to achieve the objectives and to improve employee performance (Alsaad \& Almaamari, 2020). In enhancing the performance of workers, several factors play an important role. The various types of activities used to meet your expectations are dealt with by all organizations. HRM is one aspect of management strategies planned or applied to generate human components. The importance of delivering instruction and not be set aside at any point of growth human resource practices. It has been said for a long time, and based on studies that there is a connection between training practices and employee performance (Hafeez \& Akbar, 2015).

In order to enhance employee performance, past studies that conducted training are clarified as the official continuing learning activities. An organization that does not have training for its workers will not achieve the targets and does not perform successfully in the market (Khalid, Islam, \& Ahmed, 2019). The training encourages the employee to take the opportunity on the market and enables the employee to take the required steps to deal with technological changes and particularly competitions (Larivière et al., 2017). The motivation for employee success is the other element that plays an important role. Motivation in all organizations is one of the most important factors. The achievement of the organizational objectives also plays a critical role. The term motivation comes from the word motivation (Rahardja, Moein, \& Lutfiani, 2018). Many previous studies highlighted the motivation, which could affect the performance of workers. According to Eldor (2017), employment performance is explained by the importance of an employee's conduct that helps achieve the organizational goals positively and/or negatively. Therefore, this paper explores the effect of preparation, motivations, and working conditions on employees' performance in the banking sector in Bahrain in light of this basic.

The paper is keen on employee achievement and considers the employee to be an important commodity that can help to develop the business. This paper's value would allow the banking industry to squander the critical variables, 
preparation, motivation, and working conditions of employee success. In addition, this study will allow banking to understand these factors, which have a crucial role in enhancing employee performance, and will also help understand the relationship between employee performance and schooling, motivation, and the work climate. More details on more research into preparation, encouragement, and working climate will be available in the following articles in the banking sector and other countries in GCC and other countries.

\section{Literature Review}

Various studies examine the effect on employee performance in different countries of preparation, motivation, and job performance. The center of the business is regarded as the workforce of any organization. Jetter et al. (2018), performance has been used as a tool for completing a particular job that has calculated its prices, precision, and speed against a previous norm. The efficiency and ability of the employee to use the new technologies could be manifested. Many studies have recently detected clear and positive linkages between human resources management activities and employee efficiency.

Many studies have confirmed that workers' efficiency can be increased by teaching staff, sense of teamwork to enhance the professional financial abilities (Hafeez \& Akbar, 2015). The employee's capacity is also improved by firms that concentrate more on developing employees' talents, expertise and skills through training and result in productive employee relationships and productive employee-employer relationships (Noe \& Kodwani, 2018). Evidence from literature studies indicates that training in conjunction with innovation is necessary to benefit employee efficiency. The paper carried out by HR found that having adequate preparation for workers helps in many ways, such as absenteeism and turnover (Khan, Abbasi, Waseem, Ayaz, \& Ijaz, 2016). A study was done by Latif (2012), In terms of knowledge worker recruitment, this is a descriptive paper on recruitment in software firms in Ireland, and an investigation into 39 software companies by 200 workers. The study collected data on the type of training and how the training affects the conservation of information (Acton \& Golden, 2003).

In the end, the training reports were optimistic for employee expectations. In addition, successful preparation increases the happiness of workers at the job they have. In another report, the company's training to the employees was not based on a course but on the input from the requested employees (Acton \& Golden, 2003). In their paper, Jaworski et al. (2018) said that the training activities workers take would help improve the level of satisfaction of current employment with the issue of 'training satisfaction aspects for workers.' The study concluded that the company needs to concentrate more on building employees and being built to satisfy its job. In a study done by Raja Abdul Ghafoor Khan (2011), The positive link between training and employee success has been demonstrated. In addition, it indicates the R square of 05.01 was conducted with Pakistan's telecommunications industry, meaning that the output of $50.1 \%$ is affected by adequate training. And T-Value 8.85 demonstrated that the training is a significant explanatory variable in employee performance. Jaworski et al. (2018) stated that the employees are seen as the key element for their success for any company.

\subsection{The impact of training on Employee Performance}

The literature review showed the metric of training and how it positively impacts employee performance and development of the organization's whole performance. Many studies have been conducted on this subject and were considered a gift in the eyes of staff, and training is one of them (Kadir \& Broberg, 2020; Alkadash \& Shahid, 2017)). According to DeSantis et al. (2014), training influences employee performance between international civil. The study used a survey for 144 staff who work in the United Nations in the supporting office for the African mission in Somalia.

The finding concluded that, in general, training boosted employee engagement on change procedures, motivation, job satisfaction, and comprehensive performance. On the other hand, Joseph-Obi \& Arugu (2019) revealed that training consolidates knowledge, skills, attributes, competencies, worker performance, and productivity in the organization. Bakker \& Demerouti (2018) indicated that the training process could change employees' attitudes and behaviors, which can motivate them and increase their knowledge and deal with their jobs according to the dynamic corporate environment in their journal. Moreover, Dearden et al. (2006) observed the measurement level of performance after finishing the training. It also estimated the impact of training on employee performance on their jobs.

By emphasizing these objectives, the study will suppose that the training is positively concerned about the employees' job performance. Many performance measures analyzed alongside compensation, performance appraisal, and organizational commitment clearly increase employee performance. According to Ciobanu et al. (2019), there was a positive correlation between the training and the employee motivation that enable the employee to be more engaged in the organization, resulting in better performance and better productivity to both of them the employee and the organization. Cole (2002), in his book "Personnel Management, theory and practice," the fifth edition, explained training as the learning activity that is managed to get specific knowledge and skills for the tasks. Moreover, he said that by focusing on the training, the tasks would be performed very well. And we see the other researchers like Morsy et al. (2016) reported that there a positive relationship between training and employee involvement. He also argued that good feelings emerge with high performance after getting the proper training.

Many aspects contribute to providing good and effective training, for example, the trainer capabilities, the right methods for delivering and conducting the training, the place that used for providing the training, and the most important 
is the content of the training provided by the trainers (Noe \& Kodwani, 2018). In training, the trainer is defined as the person responsible for the implementation of that training and who holds the main position in the organization to gain the best of the training program (Jaworski et al., 2018). One of the trainer's responsibilities is to rove from the easy tasks and role to effective communicator who provides the effort to achieve the training objectives (Besley, Dudo, Yuan, \& Abi Ghannam, 2016).

The trainers are mainly responsible for carrying out the learning in the workplace. There are some barriers to conveying effective training to the employees: the poor content and the style of conducting the training (Jaworski et al., 2018). In contrast, a good trainer should own the necessary skills that enable him to conduct the training in a powerful manner and useful. The trainer should set the training objectives and provide the manner to help them meet the organization goals (Haritha \& Reddy, 2017). According to Singh \& Mohanty (2012), commented in their study that training is a powerful tool that may use to boost the performance of the workforce and help in increasing the organization's worth; on the other side, the organization should balance this and the disbursement. Many results show that in many different industries that the training is influenced by diversity.

Obisi (2011), in their study, employee training and development in Nigerian organization, said that the importance of training program and the process of evaluating the organization must evaluate the training program regularly by seeing the organization objectives and the vision and missions to make sure that the goals and objectives are being achieved or not. The training could change the workforce ability and improve the performance of the employees. Further, the training helps the organization implement the future's expectation (Elnaga \& Imran, 2013). Many papers have made some progress in this field by conducting research and looking at the performance in terms of the employees' performance (Khan et al., 2016; Acton \& Golden, 2003; Valliappan, et al., 2020). In contrast, the other researchers extended to the outlook of performance of the organization. On the other side, employee performance is viewed as a study since employee performance impacts the organization's whole performance. Based on that, Elnaga \& Imran (2013) mentioned that an employee's competencies could be changed and improved by training practice. Moreover, it improves the employees' overall performance to perform in a professional manner and promote the knowledge, gain the skills, and the desirable attitudes required for the organization and its future.

The earlier study on training and employee performance has shown that there are interesting findings on this point. The training practice has been seen to make performance growth and improvement link with employees' benefit and for both the employee and organization by making a positive impact.

\subsection{The impact of motivation on the employee performance}

Motivation as a terminology came from a Latin word, and it means to move. Guay et al. (2010) said in their researches that motivation relates to driving human behavior. Motivation is considered the inner feelings that boost and help the individual have a specific manner and thoughts that the motivation may be seen from two sides. Locke \& Schattke (2019) explained that motivation is an internal feeling that starts with the human being in one way, whether purposely or unintentionally, to do the job in a good way and with high performance became more enjoyable and is not as a compulsory. Referring to the organization, employee motivation is considered one of the best policies that assist in improving the effectiveness of the work between the management and the employees in the organization. Furthermore, motivation is so essential for the organization in order to know how they motivate the employees. So, the management will make the employee understand and realize that they are appreciated, and the organization keeps them in their consideration. That feeling will reflect on the employees and increase the organization's belongs, which keeps them motivated.

\subsection{The impact of the Working environment on the employee performance}

Kohun et al. (2012) explained that the working environment comprises the completely of forces, actions, and other factors that compete potentially with the other employee activities and performance. The working environment is the total of the interrelationship available within the employees and the environment where employees work. Kundu \& Lata (2017) reported that the ability to share the organization's knowledge depends on the work environment and the design that plays a role in enabling the organization to benefit from the work environment as an asset. This helps the organization improve their effectiveness and makes the employee able to benefit from the knowledge. But he debated that the working environment is prepared and designed to smelt the employee satisfaction and flow the ideas and exchange them in a very healthy place in high productivity. Johnson et al. (2020) defined the working environment as a complex of three sub environments the human environment, the organizational environment, and the technical environment.

The human environment means the peers who surround the employees, and the others like the team and the workgroup, the leadership, management, and the interactional issues. The technical environment is referring to the tools, equipment, any physical or technical elements, and the technological infostructure. The technical environment helps the employee to be more able to do their job and perform their responsibilities and activities. The working environment supports the informal interaction in the organization, which becomes an opportunity to share the knowledge and exchange them in a fruitful manner. 


\section{Conceptual Framework}

It is a research support paper by Grant \& Osanloo (2014). It is seen as a framework focused on the comparable projects to or representing the hypothesis of the analysis. SO, it is a strategy that helps the researcher establish his shuttle or investigation. The conceptual structure serves as the basis for constructing the building by the researchers. The position of the theoretical structure for a travel plan was compared by (Miller, Sinclair, and Kostolnick, 2007; Alkadash, 2015). This map leads you to the desired route if you need to go to a certain destination. The theoretical structure guides researchers so that they stay on course and do not deviate from the boundaries of the theory that eventually contributes to university. Mensah, Agyemang, Acquah, Babah, and Dontoh (2020) synchronized the theoretical framework as a basic theory of human behavior that could support the research.

Independent Variables: $\quad$ Dependent Variable:

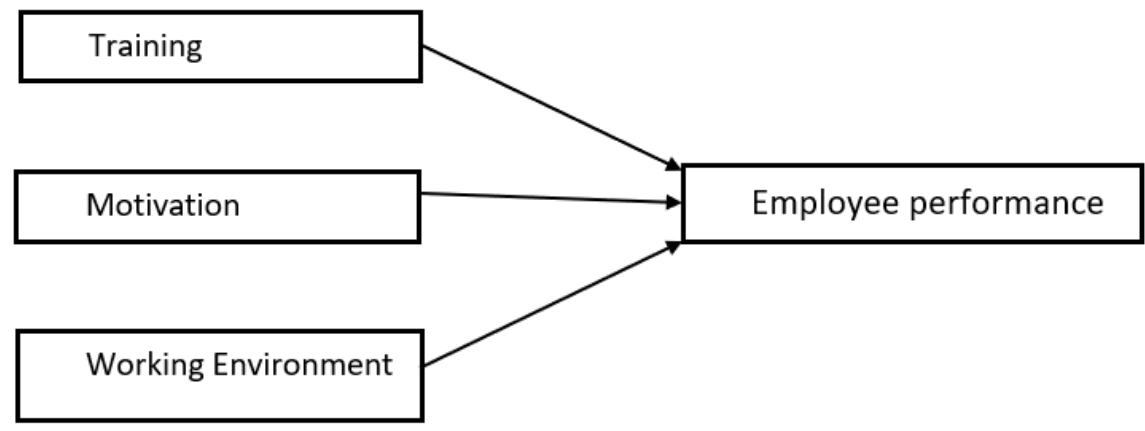

Figure 1. Conceptual Framework

\section{Limitations and Recommendations}

The study aims to review the recent studies in Bahraini banks and not include the other Banks in the GCC. Therefore, the findings will not apply to other GCC where they face the same situation. Therefore, there are different indicators about the performance of employees not included in this paper due to time limitation. Additionally, the study deals with the training, motivation, and working environment only; there are more factors impacting the banking sector that are not accounted for it.

\section{Conclusions}

The study's main objective is to review the impact of training, motivation, and working environment on the performance of the employees that work in the banking sector in the kingdom of Bahrain. The main principle of this is to understand the impact of the independent variables training, motivation, and working environment on employee performance. Banks that are well-trained, motivated, and have a good work environment are the main aim of this study and explore them on employee performance. Bahrain's banks were taken to examine its effectiveness.

Remarkably, the study observed that several studies care and give more emphasis on the training, motivation, and work environment to improve employee performance. Therefore, the employees are clearly gaining superb ability to provide creative solutions and have high performance. Finally, this study suggests having further studies to add more value to the body of knowledge.

\section{References}

Acton, T., \& Golden, W. (2003). Training the knowledge worker: a descriptive study of training practices in Irish software companies. Journal of European Industrial Training.

Alkadash, T. M., \& Shahid, M. (2017). Does Human Resource Practices Affect Perceived Organizational Support? An Empirical Study In Palestine Telecommunication Firms. International Journal of Current Research, 9(09), 58036-58042.

Alkadash, Tamer M, Almaamari, Qais, Al-Absy, Mujeeb, \& Raju, Valliappan (2020). Theory of Transformational Leadership towards Employee Performance as Sequence of Supply Chain Model: The Mediating Effect of Job Autonomy in Palestine Banks during COVID-19 Pandemic. International Journal of Supply Chain Management, 9 (5), 256-263.

Alkadash, Tamer M.(2015). The Implications of Employee Training Programs on The Employee Productivity A Study with reference to Private Sector Organizations in Palestine. International Research Journal of Business and Management, 8 (6), 01-10.

Alsaad, L. H., \& Almaamari, Q. A. (2020). A SEMI LITERATURE REVIEW OF FACTORS INFLUENCING EMPLOYEE'S PERFORMANCE AT BANKING SERVICE. International Journal of Management (IJM), 11(8). 
Bakker, A. B., \& Demerouti, E. (2018). Multiple levels in job demands-resources theory: Implications for employee well-being and performance. Handbook of Well-Being.

Besley, J. C., Dudo, A. D., Yuan, S., \& Abi Ghannam, N. (2016). Qualitative interviews with science communication trainers about communication objectives and goals. Science Communication, 38(3), 356-381.

Ciobanu, A., Androniceanu, A., \& Lazaroiu, G. (2019). An integrated psycho-sociological perspective on public employees' motivation and performance. Frontiers in Psychology, 10, 36.

Cole, G. A. (2002). Personnel and human resource management. Cengage Learning EMEA.

Dearden, L., Reed, H., \& Van Reenen, J. (2006). The impact of training on productivity and wages: Evidence from British panel data. Oxford Bulletin of Economics and Statistics, 68(4), 397-421.

DeSantis, C. E., Lin, C. C., Mariotto, A. B., Siegel, R. L., Stein, K. D., Kramer, J. L., ... Jemal, A. (2014). Cancer treatment and survivorship statistics, 2014. CA: A Cancer Journal for Clinicians, 64(4), 252-271.

Eldor, L. (2017). Looking on the bright side: The positive role of organisational politics in the relationship between employee engagement and performance at work. Applied Psychology, 66(2), 233-259.

Elnaga, A., \& Imran, A. (2013). The Effect of Training on Employee Performance. European Journal of Business and Management, 5(4), $137-147$. https://doi.org/10.2991/gecss-14.2014.90

Fawad Latif, K. (2012). An integrated model of training effectiveness and satisfaction with employee development interventions. Industrial and Commercial Training, 44(4), 211-222.

Firth, J., \& Carroll, B. (2016). Leadership and power. Routledge New York.

Grant, C., \& Osanloo, A. (2014). Understanding, selecting, and integrating a theoretical framework in dissertation research: Creating the blue print for your house. December 2014. ed.

Guay, F., Ratelle, C. F., Roy, A., \& Litalien, D. (2010). Academic self-concept, autonomous academic motivation, and academic achievement: Mediating and additive effects. Learning and Individual Differences, 20(6), 644-653.

Hafeez, U., \& Akbar, W. (2015). Impact of training on employees performance (Evidence from pharmaceutical companies in Karachi, Pakistan). Business Management and Strategy, 6(1), 49-64.

Haritha, M., \& Reddy, P. R. (2017). Training: A key component of human resource development initiatives. International Journal of Management Research and Reviews, 7(9), 902-912.

Jaworski, C., Ravichandran, S., Karpinski, A. C., \& Singh, S. (2018). The effects of training satisfaction, employee benefits, and incentives on parttime employees' commitment. International Journal of Hospitality Management, 74, 1-12.

Jetter, J., Eimecke, J., \& Rese, A. (2018). Augmented reality tools for industrial applications: What are potential key performance indicators and who benefits? Computers in Human Behavior, 87, 18-33.

Johnson, J. V, Gardell, B., \& Johannson, G. (2020). The psychosocial work environment: work organization, democratization, and health: essays in memory of Bertil Gardell. Routledge.

Joseph-Obi, C., \& Arugu, O. N. (2019). THE IMPACT OF WORKERS TRAINING ON THE ORGANIZATIONAL PERFORMANCE OF THE STAFF OF THE MINISTRY OF LABOUR AND PRODUCTIVITY, PORT HARCOURT. Ife PsychologIA, 27(2).

Kadir, B. A., \& Broberg, O. (2020). Human well-being and system performance in the transition to industry 4.0. International Journal of Industrial Ergonomics, 76, 102936.

Khalid, N., Islam, D. M. Z., \& Ahmed, M. R. M. (2019). Sentrepreneurial Training and Organizational Performance: Implications for Future Humanities \& Social Sciences Reviews, 7(2), 590-593.

Khan, A. A., Abbasi, S., Waseem, R. M., Ayaz, M., \& Ijaz, M. (2016). Impact of training and development of employees on employee performance through job satisfaction: A study of telecom sector of Pakistan. Business Management and Strategy, 7(1), 29-46.

Kohun, F., Skovira, R. J., \& Burčik, V. (2012). Decision-making in the context of its socialcultural environments: A proposed research model. Issues in Information Systems, 13(2), 320-327.

Kundu, S. C., \& Lata, K. (2017). Effects of supportive work environment on employee retention. International Journal of Organizational Analysis.

Larivière, B., Bowen, D., Andreassen, T. W., Kunz, W., Sirianni, N. J., Voss, C., ... De Keyser, A. (2017). "Service Encounter 2.0": An investigation into the roles of technology, employees and customers. Journal of Business Research, 79, 238-246.

Locke, E. A., \& Schattke, K. (2019). Intrinsic and extrinsic motivation: Time for expansion and clarification. Motivation Science, 5(4), 277-290. https://doi.org/10.1037/mot0000116

Mensah, R. O., Agyemang, F., Acquah, A., Babah, P. A., \& Dontoh, J. (2020). Discourses on Conceptual and Theoretical Frameworks in Research: Meaning and Implications for Researchers. Journal of African Interdisciplinary Studies, 4(5), 53-64.

Miller, S. A., Sinclair, S., \& Kostolnick, C. (2007). The Effects of Early Intervention and Parent Training on Vocabulary Development for the AtRisk Preschool Child. Perspectives In Learning, 8(2), 4.

Morsy, M. A., Ahmed, G. S., \& Ali, N. A. A. (2016). Impact of effective training on employee performance in hotel establishments. International Journal of Heritage, Tourism, and Hospitality, 10(1/2).

Noe, R. A., \& Kodwani, A. D. (2018). Employee Training and Development, 7e. McGraw-Hill Education.

Obisi, C. (2011). Employee training and development in Nigerian organisaitons: Some observations and agenda for research. Australian Journal of Business and Management Research, 1(9), 82.

Osabiya, B. J. (2015). The effect of employees motivation on organizational performance. Journal of Public Administration and Policy Research, $7(4), 62-75$.

Rahardja, U., Moein, A., \& Lutfiani, N. (2018). Leadership, competency, working motivation and performance of high private education lecturer with institution accreditation B: Area kopertis IV Banten province. Man India, 97(24), 179-192.

Raja Abdul Ghafoor Khan, F. A. (2011). Impact of Training and Development on Organizational Performance. Global Journal of Management and Business Research, 63-68.

Singh, R., \& Mohanty, M. (2012). Impact of Training Practices on Employee Productivity: A Comparative Study. Interscience Management Review, (22), 2231-1513.

ZEBERGA, H. (2019). THE IMPACT OF TEAMWORK AND ORGANIZATIONAL COMMITMENT ON EMPLOYEES'PERFORMANCE IN CASE OF DASHEN BANK SELECTED BRANCHES IN ADDIS ABABA. St. Mary's University. 